\title{
Crise da tradição e precariedade contemporânea: inadequação predatória de modelos em A paixão de Amâncio Amaro, de André Laurentino
}

\author{
Crisis of the tradition and contemporary precariousness: \\ predatory inadequacy of models in A paixão de Amâncio Amaro, by André Laurentino
}

Valdemar Valente Junior

Universidade Castelo Branco - Rio de Janeiro - Brasil

$\diamond$

\begin{abstract}
Resumo: Este artigo tem por objetivo detectar elementos da crise contemporânea no âmbito da cultura brasileira, tendo em vista a possibilidade de uma leitura crítica acerca do Nordeste brasileiro a partir de uma análise do romance A paixão de Amâncio Amaro, de André Laurentino. Desse modo, a região mais pobre do Brasil insere-se no âmbito de uma prática consumista que se confirma nas formas do capitalismo predatório sem que a isso correspondam possibilidades concretas de ascensão social de sua população. Na obra, inserem-se ainda questionamentos acerca dos conflitos de suas personagens em um cenário de ação marcado por forte atraso. Nesse contexto, vários símbolos da cultura são esvaziados de significado em favor de posturas que os relegam a um plano de inferioridade, no que diz respeito apenas à afirmação de símbolos do consumo alienado.
\end{abstract}

Palavras-chave: Literatura contemporânea; Nordeste brasileiro; Sociedade de consumo

\begin{abstract}
This article aims to detect elements of the contemporary social crisis within the Brazilian culture, in view of the possibility of a critical reading about the Brazilian Northeast, from an analysis of the novel A paíxão de Amâncio Amaro, by André Laurentino. Thus, the poorest region of Brazil is part of a consumerist practice confirmed in the forms of the predatory capitalism without corresponding concrete possibilities for social advancement of its population. This work also addresses questions about the inner conflicts of their characters in an action scenario marked by strong backwardness. In that context, several symbols of culture lose their meaning in favor of postures that relegate them to an inferior plan, with regard only to the claim symbols of the alienated consumption.
\end{abstract}

Keywords: Contemporary literature; Brazilian Northeast; Consumer society

\section{Introdução}

A tradição do romance nordestino, de sua gênese aos dias atuais, tem sofrido mudanças que interferem na forma com que a construção da identidade brasileira consolida seu espaço de atuação. No século XIX como hoje há uma imensa necessidade do país revelar a si mesmo seus lugares mais remotos como compensação à desigualdade e à injustiça que a grande maioria do povo enfrenta. Assim, a urgência do Nordeste mostrar-se em sua condição resulta em modelos de idealização da situação do homem submetido à secura da terra e à escassez de bens. Nesse rastro, pontificam os romances $O$ sertanejo (1875), de José de Alencar, e $O$ cabeleira
(1876), de Franklin Távora. Os dois escritores têm projetos curiosos. O primeiro pretende mapear a extensão do país, a exemplo da diversidade das personagens que cria. O outro, busca estabelecer uma linha divisória entre as literaturas do Sul e do Norte.

Fica evidente que a diversidade narrativa em um país das dimensões do Brasil suscita a fixação de vários aspectos regionais, a exemplo da saga gauchesca, de Simões Lopes Neto a Érico Veríssimo, do regionalismo baiano, de Jorge Amado a Adonias Filho, ou da aventura amazônica, de Dalcídio Jurandir a Márcio Souza. Pode-se pensar que a intenção desses autores discrepe, tendo, em poucos casos, algum nível de aproximação. No entanto, essa produção ajuda a territorializar um projeto 
de fixação, mesmo sendo inevitável não haver qualquer dissensão. O momento máximo da eclosão regionalista corresponde à abertura da produção livresca ao interesse da classe média, o que se faz notar a partir da década de 1930. Desse modo, José Américo de Almeida, Graciliano Ramos, Rachel de Queiroz, José Lins do Rego, ou mesmo Amando Fontes e Clóvis Amorim, expressam o lugar de um Nordeste que se revela em sua realidade social, a partir da prosa de ficção como meio de aproximação do Sul-Sudeste com a região mais pobre do país.

Esse estado de consciência ainda não fora atingido pela intervenção capitalista em seu programa de desagregação da ordem estabelecida como referendo da tradição que se arrasta no tempo. Apesar da carga de denúncia que agregam, obras como Vidas secas (1938) e Fogo morto (1943), em que pese o nível de resolução formal que encerram, sobretudo a primeira, por se situarem no espaço de um Nordeste pré-capitalista, não concorrem para a consolidação do romance como possibilidade dialógica da sociedade em processo. Apontam, isto sim, para situações imutáveis que se prolongam como herança da escravidão e se confirmam na improdutividade do latifúndio como retrato do atraso secular de um país de economia dependente.

Por sua vez, a inserção brasileira no plano do consumo de bens como sinônimo de sua equiparação ao estágio civilizador das nações desenvolvidas resulta em malogro. Os planos de equiparação social, no âmbito das condições básicas de acesso à saúde, à educação e ao saneamento, ficam a dever. Em lugar disso, tendo em vista a fragilidade sua economia, o Nordeste recebe o impacto violento do consumismo predatório como parte da disseminação da cultura de massas, o que concorre para a desestruturação dos modelos de uma cultura da permanência que se esvazia, dando lugar ao que de pior pode representar a posição sem crítica da máquina capitalista em sua cegueira e sua sede de lucros. Assim, é inevitável que a redefinição da estrutura social e econômica afetada não tenha como efeito a distinção do ponto de vista de que seus escritores se servem hodiernamente como elementos que configuram o cerne do debate acerca do Nordeste e seu descompasso ante a ordem que se impõe.

Por isso, o enfrentamento da situação apresenta certa precariedade de sentido, uma vez que as formas da tradição cultural não resistem ao apelo ostensivo do consumo que se locupleta da fragilidade que vitima a região. Obviamente, a concepção de regionalismo, no que concerne à produção narrativa ambientada no Nordeste, tem sua atenção voltada para um esquema de fatores de sentido dinâmico que leva em conta outro nível de realidade, diferente da concepção de um Nordeste estático, em vista da situação de desigualdade social. Não cabe mais o distanciamento como arma de enfrentamento do sistema, senão o entendimento da complexidade das relações entre capital e trabalho no plano da precariedade que acena para o fim das ideologias e as substitui pelas relações de mercado como marco decisivo. Desse modo, vislumbra-se um outro Nordeste, destituído de suas marcas de singularidade, no que tange à capitulação de seus mitos mais significativos, que agora dividem espaços com o consumo, em condição de absoluta desigualdade. Assim, a utopia do "Nordeste independente", patenteada na canção de Bráulio Tavares e Ivanildo Vila Nova, difere do plano de inserção que estabelece sucessivas relações em diferentes esferas.

No âmbito da escrita, surge a prosa de ficção de Raimundo Carreiro, Antônio Carlos Viana, Ronaldo Correia de Brito e Francisco J. C. Dantas, entre os mais destacados autores nordestinos desse momento. Suas respectivas obras habitam o eixo da literatura contemporânea agravando o debate da narrativa como polo de atração de múltiplos questionamentos. A relação do homem com o meio é acrescida de situações inusitadas, no que concerne às diversas narrativas já ambientadas no sertão nordestino. A visão do presente personifica a ideia do Nordeste que se multiplica em função da crise, relacionando-se com suas formas sedimentadas de modo a caracterizar enfoques diferentes acerca de elementos do patriarcalismo postos em cheque pela pulverização progressiva das manifestações do poder que se impõem como expressão contemporânea. Ao recorrer à cronologia do que aparentemente tangencia a tradição, há uma deliberada sublevação da ordem prescrita na trajetória das narrativas que têm como cenário de ação o Nordeste, visitado a partir de um olhar que o distingue de abordagens passadas.

Assim, no conjunto da produção brasileira contemporânea, alguns autores promovem um modo específico de análise crítica que aponta para a desgeografia cultural a que a região se encontra submetida, em vista da demanda de bens oferecidos sem consulta prévia, e que rapidamente retroagem à condição de obsolescência, para que imediatamente outros tantos ocupem esse lugar. Essa ciranda reafirma o esvaziamento do valor dos materiais de cultura, que configuraram o plano de caracterização do que hoje perde essência e sentido. Por isso, a imagem do Nordeste, idealizada ao longo do tempo, cede espaços à refração de um universo precarizado, onde as proposições de superação dos índices de pobreza extrema esbarram na inviabilidade do próprio sistema, refém do capital especulativo, que dissemina uma produção inócua, destituída de valor primordial. Assim, vários símbolos da cultura nordestina perdem espaços para expressões de configuração econômica e cultural que contribuem decisivamente para a fixação de um contexto de outra feição. 
Desse modo, A paixão de Amâncio Amaro (2005), de André Laurentino, reitera no âmbito da narrativa a proposta de desritualização do Nordeste ancestralizado, na medida em que contribui como índice de negação da ordem sedimentada ao confrontá-la à determinação contemporânea das mudanças que se impõem. A situação original do homem nordestino tem o acréscimo da desestruturação da tradição pela via do descompasso que se acentua na bizarria das personagens. Decorre daí, no plano textual, o encaminhamento de questões prementes, a partir da realidade presente, como formas desagregadas do contexto que agrava os conflitos e destitui a expectativa em torno de alguns tipos retratados. A oscilação vivida pela população sertaneja, atingida pelo surto efetivo de transformações, é agravada pela pressa que se impõe, no sentido de que as perdas decorrentes desse processo assumem um caminho sem retorno. Assim, por meio da narrativa de André Laurentino, o Nordeste pode ser revisto sob uma perspectiva distanciada, de onde se percebe o aniquilamento de valores culturais, a partir da ação direta da ordem irracional do consumo sem crítica.

\section{A invenção do Nordeste}

A perda da identidade de Amâncio Amaro ou a multiplicidade dos nomes que carrega corresponde à ideia de um universo que se multiplica para em seguida fragmentar-se, a exemplo das relações de troca no mercado pela imposição de interesses muitas vezes divergentes. Os vários nomes próprios o levam a ter certeza do que representa o meio em que vive, na medida em que sente o desejo de nomear as coisas para que estas façam sentido. A necessidade de nunca esquecer envolve a memória como matéria diária e confirma esse exercício como ferramenta indispensável à regulagem da condição humana, diante da dissipação das coisas no rodamoinho das sensações. O sertão do menino Amâncio Amaro é uma terra onde tudo se perde, inclusive a memória, sua maior obsessão, quando esquece do recado da avó e passa a lembrar da série de seus nomes, em movimento de ir e vir do que representa a perda do significado mais expressivo dos bens que definem sua terra. Enquanto isso, a lida prossegue nos partidos de cana, ritmado pelo barulho da foice, na preparação do solo para a queimada.

Em vista disso, se oferece ao leitor a ampliação de seu foco de visão, por conta da dissolução de modelos que assumem situações de desvio, caracterizando-se estas pelo descompasso das formas do arcaico em face do progresso material de sentido refratário. A expectativa da mudança coloca-se em posição a reboque das narrativas, concorrendo para que os meios inerentes à reforma procedida pela força do capital apontem apenas a direção do precário. Os meios de produção estão ligados ao extremamente necessário, entrando em choque com a condição de inaptidão do homem à ordem que se impõe. "Tanto a reação monocultural como as reivindicações identitárias podem ser interpretadas como estratégias de resistência ou de mudança dessa situação de mistura e incerteza" (SEMPRINI, 1999, p. 40). Daí A paixão de Amâncio Amaro evidenciar o lugar do sertanejo afetado por um processo em via de mão única, sem possibilidade de retorno. O menino coloca-se à margem da ordem produtiva do sertão que se reinventa na imaginação como eixo do princípio narrativo de que a obra se serve. A saga do sertanejo, na aventura de inventariar seu próprio sentido, quando não de reelaborar sua relação com a terra, com a qual se confunde, em vista do determinismo que vai do umbigo à cova, corresponde à invasão que a ambos fragiliza. O homem e a terra são destituídos um do outro pela alienação que os desabilita e os enfraquece:

\begin{abstract}
Caberia, pois, unicamente à memória coletiva nacional integrar a diversidade das populações e das classes sociais, definindo desta forma a identidade do grupo como um todo. Neste caso, apesar das transformações tecnológicas, da globalização da economia, a cultura nacional, enquanto formadora das relações identitárias, estaria incólume às mudanças atuais (ORTIZ, 1998, p. 116-117).
\end{abstract}

A imagem do sertão, onde prevalecem as formas do trabalho rústico, tem como elemento atenuador o jogo lúdico que faz do menino o receptáculo das expectativas que se fundem ao princípio da estranheza. Santana é uma vila onde a cobiça humana não vinga, uma vez que foi formada por índios e escravos, livres de holandeses, pernambucanos e portugueses. Por isso, a pobreza da terra funciona como fator favorável ao isolamento. A bizarria do elemento humano e a situação da população que não aumenta nem diminui concorrem para que o lugar, em sua condição de espaço definido no imaginário coletivo, se transfigure, ensejando situações que se apresentam como tema. A beleza de Culadinha, por exemplo, só existe para ela própria, ao contrário da opinião dos demais, que a julgam feia. No entanto, isto só ocorre diante do espelho, pois a menina tem inveja da própria imagem, querendo que a vida se dê do outro lado do pequeno caco quebrado que encontrou no chão, caído de uma fantasia, por ocasião do desfile do maracatu, no domingo de Carnaval, quando descobre seu rosto refletido.

As aparências e representações são subvertidas, se for pensado o sertão como manifestação de uma cultura sedimentada, sem alternância. Para isso concorre o modo supostamente paralisado, acerca do qual não faz sentido qualquer apelo capaz de inverter a lógica de um esquema tradicional. No entanto, a quebra da hierarquia acontece a partir da sucessiva aparição de personagens transgressoras 
como manifestação inusitada de posturas inimagináveis. A isso é acrescida a religiosidade popular, a exemplo do candomblé, que no Nordeste amplia o significado da cultura africana, presente em boa parte do país. José Aurino Curió acrescenta aos tambores do culto aos orixás o canto das lavadeiras, na beira do açude, escondendo-se e disfarçando-se, na medida em que esta é a sua condição. $\mathrm{Na}$ festa de eleição da Rainha do Milho, desfaçara-se de poste, ainda que não haja luz elétrica em Santana, olhando pela primeira vez para Culadinha, a menina feia, por quem se apaixona, ao vê-la colocar a faixa na candidata vencedora. Na condição de míope, ignora como são as coisas, acreditando que são tal e qual lhes enxerga.

Entre o canavial e a vila, Amâncio Amaro medita em torno do que não faz a menor ideia de como seja. Não sabe calcular, tampouco medir o tempo, uma vez que só concebe as coisas a que pode ver e dar forma. Assim, diante de um sertão pouco sujeito a mudanças, configura-se outra concepção, que busca romper a lógica das relações arraigadas no tempo. A ausência de contato dos habitantes da vila, isolada do mundo moderno, sugere a superação de questões de ordem técnica, que o sertanejo contorna lançando mão de expedientes incomuns. Os bens facilmente acessíveis à ordem econômica atuam como entrave, dando margem à precariedade no âmbito local e induzindo a uma aproximação com os meios que visam sustar esse impasse. "A pureza é uma visão das coisas colocadas em lugares diferentes dos que elas ocupariam, se não fossem levadas a se mudar para outros, impulsionadas, arrastadas ou incitadas" (BAUMAN, 1998, p. 14). Desse modo, instaura-se um terceiro termo à escassez da oferta de produtos, na demanda do consumo supérfluo e na expectativa em torno da chegada desses mesmos produtos, aliada à carga de alienação e aos estragos que os acompanha:

A transformação cultural é um eufemismo para o processo pelo qual algumas formas e práticas culturais são expulsas do centro da vida popular e ativamente marginalizadas. Em vez de simplesmente caírem em desuso através da Longa Marcha para a modernização, as coisas foram ativamente descartadas, para que outras pudessem tomar seus lugares (HALL, 2003, p. 248).

O sertão se reconstitui na pluralidade que a narrativa de André Laurentino lhe confere, condenado à dimensão esvaziada das coisas inerentes à contemporaneidade. Diante da falta de limites no universo de manifestações que não respeitam qualquer obstáculo, A paixão de Amâncio Amaro aponta para a derrocada de uma cidadela até então intocável. Dessa situação torna-se impossível retroagir, na medida em que a estrutura fragilizada do grupo social essencialmente agrário não tem como concorrer com os meios de produção industrial que lhes arremata os produtos a preço irrisório e os renegocia, embutindolhes o elevado valor de novidade imposto pelo mercado de consumo. "A própria ideia de desenvolvimento pressupõe o horizonte de um não desenvolvimento, onde as diversas competências estão supostamente envolvidas na unidade de uma tradição..." (LYOTARD, 1989, p. 48). A concepção do sertão nordestino, em meio à inépcia do sistema que negocia os elementos de sua cultura, tende a ser reavaliada, em face da inserção dessa região nos parâmetros da ordem capitalista que lhe podem soar de forma estranha, tendo em vista a dose de inaptidão que ainda perpassa esse negócio:

\footnotetext{
Mas, no mundo moderno, que perdeu a crença no tempo linear e nos mitos que respondiam às contradições, que vive a história como mudança e soma de exceções, a ironia acompanha a analogia. Toda tentativa de buscar o manancial original, a fonte das correspondências, está corroída pelas transformações sem regras fixas da modernidade (CACLINI, 2000, p. 112).
}

As relações nesse sertão desentranhado do aspecto conceitual da região suscitam a condição inevitável de um olhar que vem de fora, que passa a concorrer com elementos de natureza interior, problematizados, a partir da inserção de mecanismos inerentes à subdivisão do trabalho. Assim, o isolamento de Santana tende a não suportar os apelos da sociedade de consumo, transformado em simples elemento de retórica. Os mitos e lendas que perpassam a relação entre o homem e a terra buscam soluções que se alternam, na medida em que esse microcosmo acaba por dinamizar seus pontos de interesse. Por isso, José Aurino Curió não captura o passarinho que lhe empresta o nome, servindo-se do ardil de colocar como armadilha visgo de jaca mole em três alçapões com sementes de alpiste, capim e maconha, esta última considerada excelente para o apetite sexual das aves. Na verdade, a maconha advém do cultivo clandestino que seu irmão introduz no milharal onde trabalha. Disfarçadas entre os pés de milho, as mudas de maconha crescem, dando margem à indagação sobre a questão que envolve o cultivo e o consumo dessa droga, tendo como meio produtor o sertão pernambucano.

José Aurino Curió ganha a vida construindo gaiolas, o que lhe acrescenta o curió ao nome. No entanto, a paixão pelos passarinhos se acresce do corpo de Culadinha, que a ele se entrega, pretextando em família, para poder encontrá-lo, o ardil de lhe levar um prato de comida. Para José Aurino, a captura do curió de canto, seguido do encontro furtivo, resulta em casamento. Surpreendida pelo pai, Culadinha vê desmascarada a farsa tão bem urdida, o que lhe resulta na obrigação de se casar com José Aurino, que lhe repara o dano moral, tão caro ao modelo de sociedade patriarcal. No entanto, a insistência 
em legitimar tradição acaba por ruir. A instituição do matrimônio tende a ser questionada, quando o marido se mostra refratário ao trabalho, passando dias seguidos deitado na rede a escutar o canto dos passarinhos. A ordem familiar, portanto, tem seu sentido comprometido pela inaptidão de José Aurino Curió ao cumprimento das funções de provedor. Na verdade, o casamento por imposição não se confirma em sua função, ficando sua eficácia restrita ao cumprimento único do dever conjugal, no que se refere ao desejo sexual compulsivo da esposa.

A paixão de Amâncio Amaro concorre para efetivar o descumprimento de códigos que norteiam o princípio conservador de uma sociedade fechada em seus valores. Para tanto, atuam elementos que destoam do sentido de linearidade resultante da imposição da ordem como resposta positiva às circunstâncias que atingem a população pobre e sem expectativas. Em vista disso, a narrativa caminha em sentido contrário, operando um corte específico no que corresponde à tradição que sucumbe à avalanche de elementos invasores. Por isso, "a descolonização começa para o nativo como uma tábula rasa - um vazio, uma primeira página - sobre a qual está registrada a completa desordem do desejo de descolonização" (BHABHA, 2011, p. 169). Estamos diante de uma situação de predomínio da lógica materialista, que acelera a relação do sertanejo com uma dinâmica cuja projeção não se pode deter. O sertão verdadeiro, que evidencia as agruras da seca e da fome, cede espaços à versão inventada a partir das relações de troca que lhe ficam a dever. O entendimento acerca desse processo implica a concepção do universo da escassez, que recebe como aporte a oferta do que a indústria cultural descarta como despejo, impondo conceitos que lhes são estranhos.

\section{Entre o antigo e o novo}

O Nordeste sempre ocupou posição incômoda na cena brasileira, na condição de região marcada pelo flagelo da seca que obriga seus filhos a imigrarem para o Sudeste-Sul, em busca de trabalho e sobrevivência. Esta situação por muito tempo estigmatizou o homem à condição de retirante cuja indigência situa-se como um dos pontos altos do caráter realista que assoma o romance brasileiro, especificamente na década de 1930. Contudo, a confirmação do Nordeste como espaço emergente, aberto à oferta do consumo em sua feição contemporânea, encontra na ficção produzida nas duas últimas décadas um espaço diferencial. As forças produtivas que têm por base a dinâmica do capital não encontram resistência à preservação dos bens da cultura artesanal. "A distância entre os padrões estéticos elitistas e a competência artística das classes subalternas expressava, e reassegurava, a separação entre as classes sociais" (CANCLINI, 1983, p.52).
Por isso, esses bens descaracterizam-se de seu conceito original, obrigados a negociar sua permanência sob pena de sucumbirem à imposição compulsória que assume posições.

No plano da narrativa, imaginação e realidade situam-se de modo a estabelecer distinções entre o amor onanista que Amâncio Amaro idealiza por Luzinete e o coito das reses no pasto, em sua materialidade plena, face às situações que não podem esperar. Em seguida, o sonho o remete à ideia de um mundo de estranhezas, onde as mangas vendidas no açougue lhe emaranham os fiapos nos dentes que não tem, mas imagina ter. Além disso, os gêneros apregoados por diferentes vozes não se remetem a legumes, frutas e verduras, mas à sequência dos diferentes nomes que possui. Amâncio Amaro vê a si mesmo como as mercadorias expostas ao olhar de quem quiser pagar para obtê-las. Ao despertar do sonho, é acometido pelo medo de sair, para não ter sua lista de nomes repetidos na boca dos vendedores como pregão de feira. Ao fugir dos meninos que lhe ameaçam, montado no lombo de um jumento em disparada, percorre a extensão da feira, para espanto dos presentes, que associam sua aparição à entrada triunfal de Jesus Cristo em Jerusalém, tendo em vista a proximidade da Semana Santa.

Verifica-se no microcosmo de Santana a perspectiva de sua atividade dialógica com a força do capitalismo em sua função pragmática e a liquidação do que resta da tradição. Os apelos do corpo, aliados aos impulsos do desejo, concorrem para que A paixão de Amâncio Amaro se apresente como narrativa capaz de pôr em cheque o lugar do homem diante de uma ordem que se destitui a partir do que se instaura sem aviso prévio. Parece inegável que a sucessão de evidências corresponda à fraqueza que se estiola, em face da potência destrutora que concorre para que o fim das coisas seja o início do que ainda não se consegue perceber. Ganhar e perder fazem parte de um jogo em que o peso da derrota pode resultar em aliança provisória da vítima com o algoz, quando não em malogro absolto. "El aspecto más valioso del concepto de cultura es el concepto de diferencia, una propriedad contrativa - mas que una propriedad sustantiva - que poseen ciertas cosas" (APPADURAI, 2001, p. 15). Assim, o sertão legitima o sentido das ações que não mais remetem à tradição de cangaceiros de punhal e parabélum ou das tropas volantes do Tenente Bezerra, no encalço de Lampião e Corisco, mantendo os resquícios de um patriarcalismo que decai, atingido por forças que lhes são superiores:

Os diferentes tipos de competência cultural vigentes em uma sociedade dividida em classes derivam seu valor social do poder de discriminação social e da raridade propriamente cultural que lhes confere sua posição no sistema de competências culturais. (BOURDIER, 1998, p. 142). 
A paixão de Amâncio Amaro agencia a percepção acerca das fraturas impostas pela luta de que o sertanejo é protagonista. A observação recai sobre um modus operandi que destoa da carne seca com farinha como cultura da permanência, detectando as formas da violência que se impõe e destituindo o homem de seu espaço de fruição da vida. "Processos de mudança engendrados pela modernidade estão intrinsecamente ligados a influências globalizantes" (GIDDENS, 2002, p. 170). Não há como não capitular às ofertas em efeito cascata. Ao recorrermos a Euclides da Cunha, a partir da afirmação de que "Canudos não se rendeu. Exemplo único em toda a história, resistiu até ao esgotamento completo" (1995, p. 513), constatamos que a ingerência capitalista, em sua feição contemporânea, apresenta-se de modo devastador, a exemplo da artilharia, sob o comando do Coronel Moreira Cesar, o "Corta-cabeças", que mesmo derrotado pelos conselheiristas, tencionava varrer Canudos do mapa do sertão. Assim, a caraterização dos um microcosmo, configurado em seu caráter mitológico, tende a desaparecer pela dominação que se faz representar na dinâmica das mercadorias, inviabilizando o exercício das trocas de valor afetivo e utilitário:

\begin{abstract}
A identidade plenamente unificada, completa, segura e coerente é uma fantasia. Ao invés disso, à medida em que os sistemas de significação e representação cultural se multiplicam, somos confortados por uma multiplicidade desconcertante e cambiante de identidades possíveis, com cada uma das quais poderíamos nos identificar - ao menos temporariamente (HALL, 2004, p. 13).
\end{abstract}

José Aurino Curió, como o nome já sugere, vive em função de seus passarinhos, ao lado de Culadinha, sua mulher, expulsa da casa dos pais, que atiram à rua os seus pertences. $\mathrm{O}$ canto mavioso dos curiós alenta seus desejos, no balanço da rede, rendendo-lhe dividendos que se multiplicam apenas na imaginação. Ao mesmo tempo indaga acerca do fato de que os curiós de excelência não têm preço. Não obstante a vida de casado, Curió negligencia no cumprimento dos deveres matrimonias, além das dívidas contraídas, a que tampouco salda. Assim, disfarça-se mais uma vez e foge pelos fundos da casa, enquanto Culadinha rechaça os credores, mirando em seguida o pedaço de espelho de onde sai uma outra mulher, lindíssima, em que se transfigura. Ao acariciar o próprio corpo pensa na possibilidade de o marido conseguir trabalho e quitar as dívidas. Curió, no entanto, vive envolto por um halo de hedonismo, alheio ao trabalho como expressão sistemática da produção de bens, ou mera exigência para o sustento da vida diária. Depois de desfazer-se do disfarce de bacurau, depara-se no mato com um incorporado de Xangô, em meio a um despacho de santo, que lhe pronuncia a expressão "caldo de cana" como uma espécie de epifania.

A revelação soa como senha que o induz ao princípio da transformação da matéria-prima em produto acabado, acessível ao consumo. A conversão da canade-açúcar significa o encurtamento da relação entre a produção e a eficácia do sistema de mercado. Por conta disso, a revelação de Xangô compreende a demanda que a sociedade rural, mesmo obedecendo aos limites do precário, tende a estabelecer em sentido direto e impositivo com os elementos da técnica. O caldo de cana efetiva-se como representação da novidade que em pouco tempo torna-se obsoleta, na medida em que os apelos do capitalismo exprimem seu aspecto devastador e absoluto. A ruína do que ainda não se configurou como expressão final corresponde à agilidade da demanda reprimida do sistema que expande seus meios de atuação sem respeitar o limite das formas com que se apresentam os espaços de troca em seu perfil de dependência e fragilidade:

Acontece que a revolução burguesa raramente resolveu a questão nacional satisfatoriamente, tendo-se em conta os interesses das maiorias e minorias. Persistem e recriam-se as desigualdades sociais, culturais e raciais, além das políticas e econômicas. Em toda sociedade nacional o povo é uma estranha coletividade de cidadãos de várias e desiguais categorias, com participação às vezes extremamente desigual nos produtos das atividades nacionais (IANNI, 1997, p. 197).

Para José Aurino Curió o trabalho ligado à ordem das coisas consumíveis situa-se em um plano de alienação, estabelecida a distinção entre o sentido pragmático da sobrevivência e o caráter subjetivo do prazer. O caldo de cana, cuja extração se impõe como dificuldade, carece de modernização, através da máquina importada, fazendo com que a novidade lhe renda dividendos com os quais liquidaria os débitos, podendo dedicar-se unicamente aos passarinhos. No entanto, o Exu, santo a quem sempre se faz preciso agradar, na ausência de encruzilhada, desce no mato para receber o despacho que lhe é devido. As dívidas com os homens são possíveis de serem pagas, ao passo em que as com os espíritos do outro mundo têm juros infernais, e Curió afrontou a Exu, pensando em lhe tomar o despacho. Daí a vingança do dono dos caminhos ser inevitável. Ao olhar com interesse a oferenda do santo, seu compromisso torna-se impossível de ser quitado, cabendo-lhe o ônus consecutivo, em parcelas de liquidação infinda.

A indústria e o artesanato confundem os termos do que se considera como efetivação da técnica no âmbito das necessidades. A máquina vinda de Recife contraria a lógica do que é precário em essência, impondo-se como meio de abolição do esforço, na medida em que 
isso se atém à ideia de que ela trabalha para o homem, eximindo-o do dever de verter o suor do próprio rosto. "A articulação social da diferença, da perspectiva da minoria, é uma negociação complexa, em andamento, que procura conferir autoridade aos hibridismos culturais" (BHABHA, 2005, p. 20-21). Assim pensa José Aurino Curió, quando lhe ocorre a ideia redentora, acreditando ser possível à condição humana extinguir por completo a missão de trabalhar, em nome apenas do prazer. A contestação do trabalho se contrapõe à obrigação com Exu e a quebra de um vínculo espiritual com que a religiosidade popular busca superar a dor e o infortúnio.

Ao fugir à fúria de José Aurino Curió, seu pai, Amâncio Amaro refugia-se no canavial, como sempre faz, deixando-se levar pelo onanismo que por instantes faz com que tudo lhe pertença, em meio ao cheiro forte da plantação, quando o corpo de Luzinete, em pensamento, lhe surge despido, fazendo-lhe infringir o sentido da realidade que se apresenta impactante ao olhar. Dessa forma, os conflitos humanos se oferecem para configurar em Santana a ideia do que se apresenta ao mesmo tempo simples e complexo. O sertão se desvela a partir de cada ação humana, deflagrando, no sentido da universalidade que engendra, a sucessão dos eventos que aí têm efeito. A paixão de Amâncio Amaro serve como pretexto à decifração da cena rural como portadora de uma carga de elementos que transbordam da narrativa, oferecendo-se como possibilidade de leitura do sertão em sua imagem refletida, e por isso mesmo recriada.

\section{A chegada da crise}

José Aurino Curió aprendeu a fazer gaiolas com o velho Baltazar, escondendo-se para observar a técnica apurada do artesão. $\mathrm{O}$ velho percebe, mas não dá importância, uma vez que não se considera proprietário de qualquer patente que distinga seu trabalho dos demais. No entanto, com sua morte, José Aurino Curió passa a ser o único depositário do segredo e da perfeição dessa arte. O objeto, quase uma joia, agora funciona como mercadoria, instrumento de barganha, na medida em que é oferecido como moeda de troca à quitação da dívida contraída, na compra de uma sela a Seu Antônio Pertence. O requinte das divisões e a execução dos acabamentos fazem da gaiola peça de artesanato digna de abrigar o canário belga de Dona Eudíce, sua esposa. No entanto, a questão do pagamento prende-se ao jogo de poder pela compra da máquina de caldo de cana que tende a mudar a relação do homem com o meio, interferindo na forma de lidar com a produção, com o beneficiamento da cana de açúcar, agora explorada sob a forma de caldo.

Verifica-se uma alteração nos meios de troca, que se estabelecem pela imposição dos mecanismos de atuação de modelos que se efetivam para em seguida deixarem de ter significado. A gaiola, de que José Aurino Curió detém a manufatura, viabiliza a negociação a que se pretende, culminando no esvaziamento de seu sentido essencialmente artesanal, no âmbito das relações de negócio. "Os desafios colocados por um novo desenho do mundo impõem a revisão dos limites, não estritamente geográficos, mas aqueles sociais e culturais que diversificam todos os locais" (FERRARA, 1994, p. 169). Seu Antônio Pertence participa na intermediação da compra da máquina, na condição de quem tem contato com bancos e credores. Por sua vez, ao se negar a ficar com a gaiola, não consegue imaginar como esse fruto de invenção e inteligência possa ter sido engendrado por alguém tão indolente. Ocorre aí mais um exemplo da discussão acerca das formas de trabalho, a partir da oscilação entre o artesanato prazeroso e a produção esvaziada de sentido, resultante da condição serial que se explicita na vitória da máquina sobre as expressões simbólicas do trabalho como representação na vida diária:

O projeto de cultura que gostaríamos que vingasse numa sociedade democrática é aquele que desloca o conceito de cultura e mesmo o conceito de tradição. Em vez de tratar a cultura como uma soma de coisas desfrutáveis, coisas de consumo, deveríamos pensar a cultura como o fruto de um trabalho. Deslocar a ideia de mercadoria exibida para a ideia de trabalho a ser empreendido (BOSI, 1987, p. 38).

Assim, o agenciamento do negócio ocorre pela via da habilidade com que a gaiola se materializa em seu valor, propiciando o financiamento da máquina. A gaiola atua como instrumento de persuasão da esposa de Seu Antônio Pertence, que ao elogiar o presente faz com que o marido se incline a ajudar, reiterando sua superioridade, uma vez que, para ele, aquilo nada representa, sendo, no entanto, a salvação para as dívidas de José Aurino Curió. A máquina passa a configurar um halo de expectativas, esperada em Santana com enorme ansiedade. A aparição redentora agrega em si a promoção do culto à personalidade de que seus investidores pretendem tirar proveito. Na verdade, a esperteza e o malogro de José Aurino Curió, ao induzir Seu Antônio Pertence a lhe facilitar o acesso à máquina, correspondem às trapaças de personagens da oralidade medieval que povoam o imaginário nordestino, nas versões de João Grilo e Pedro Malasartes, difundidas pela literatura de cordel e pelo teatro popular como símbolos da sublevação provisória dos subalternos ante o poder que os domina.

A idealização da máquina de tirar o suco da cana exerce o espaço dos comentários que antecedem sua chegada. No entanto, a vingança de Exu contra José Aurino Curió faz com que a máquina chegue no mesmo caminhão, 
por uma vala aberta em Santana, que não conhece veículos motorizados, que traz também os engradados do refrigerante cujo rótulo, de desenho sinuoso, em vermelho e branco, reproduz as cores de Xangô. Daí as garrafas de conteúdo negro e espumante roubarem a cena, reduzindo à nulidade completa o significado da máquina. A oferta de produtos sucessivamente substituídos condena a máquina de caldo de cana à obsolescência, sem que haja tempo para a efetivação de sua eficácia. "A cultura deixa hoje o indivíduo desamparado, porque não é capaz de oferecer símbolos que o formem, quer dizer, que permitam sua realização como indivíduo" (SUBIRATS, 1991, p.78). A sedução do refrigerante consumido no mundo inteiro é capaz de lhe subtrair a possibilidade de afirmação, servindo para contrapor ao parasitismo da economia local uma dinâmica para a qual não há como ser possível qualquer nível de concorrência:

A fúria devoradora deste obsceno maquinismo tecnoburocrático - auto-reproduzido e incessantemente aperfeiçoado pelo desenvolvimento capitalista encarna a mais insidiosa forma contemporânea da crueldade. Ao produzir o nexo de equivalências e vínculos entre homens e coisas, naturaliza a vontade de domínio como desejo do mais forte e dissemina a espoliação, em todas as versões mais sutis e sedutoras, como modus operandi da socialização (DIAS, 2004, p. 17).

O sucesso e o fracasso aliam-se à mesma situação, na medida em que as formas do capital são fluidas e mudam de território com rapidez, alterando o foco de interesse do que deixa de ter significado. Os credores voltam-se impiedosos contra o comprador inadimplente e as gaiolas passam a não representar absolutamente nada no mercado de bens em que as garrafas de refrigerante são como vedetes. Desse modo, verifica-se a inversão completa do valor das necessidades, na medida em que o caminhão da Coca-Cola antecipa-se às prioridades capazes de poder aprofundar a relação do homem com os bens da terra. "En fin, las relaciones de explotación/dominación generan conflictos personales y sociales en el ámbito de la experiencia social y humana" (MIGNOLO, 2003, p. 48). As relações de troca no mundo dos negócios são uma abstração para José Aurino Curió, que recebe um encargo para o qual não fora preparado.

A imposição dos produtos supérfluos em agrupamentos humanos sem qualquer outra condição, senão a de deter a patente do que lhe é essencial, confirma-se na permanente pobreza que os atinge. No entanto, não existe limite à ambição das frentes abertas pela especulação, desqualificando a tradição em nome da velocidade das ações que destituem o sentido e a eficácia de bens de origem exclusiva, ligados aos costumes da terra. "Defino como predatórias aquelas identidades cuja mobilização e construção social requerem a extinção de outras categorias sociais próximas" (APPADURAI, 2009, p.46). O que lhes vem em substituição corresponde à inadequação do que o sistema considera obsoleto, ocupando de modo compulsório o lugar de certos usos que se tornam inócuos. A tentativa de manter os hábitos da tradição não tem como resistir ao massacre que retira a função de coisas tornadas termos acessórios, quando não de objetos destinados ao consumo especifico da curiosidade turística, sob o invólucro de novidade aos olhos incautos de quem não as reconhece em sua função essencial, convertidas em objeto de mera contemplação e curiosidade:

O mercado não pode sedimentar tradições pois tudo o que produz desmancha no ar devido à sua tendência estrutural a uma obsolescência acelerada e generalizada não somente das coisas, mas também das formas e das instituições. O mercado não pode criar vínculos societários, isto é, entre sujeitos, pois estes se constituem nos processos de comunicação de sentido, e o mercado opera anonimamente mediante lógicas de valor que implicam trocas puramente formais, associações e promessas evanescentes que somente engendram satisfações ou frustrações, nunca, porém, sentido (MARTIN-BARBERO, 2001, p. 15).

José Aurino Curió resolve batizar seu filho recémnascido, Amâncio Amaro, com o acréscimo do nome de todos os credores, buscando livrar-se das dívidas. No entanto, sua mulher tenta sem êxito roubar uma garrafa do líquido espumante, chegando a prová-lo, para tentar reproduzi-lo através de receita caseira, pretendendo vender o produto pela metade do preço, o que inviabilizaria a venda do original e recuperaria, em seguida, a credibilidade do caldo de cana. Em vão tenta também insinuar que o refrigerante, antes de ser um poderoso afrodisíaco, constitui-se no responsável por doenças sem explicação. Para tanto, justifica o crescimento do ventre, não à gravidez, mas ao inchaço, decorrente de sua ingestão. Assim, nascido desse momento de crise e contradição, Amâncio Amaro, menino com mais cinquenta nomes, encontra seu calvário na adolescência, quando o onanismo que sempre o faz imaginar Luzinete é descoberto em meio ao canavial por Hendique, o rival de quem quebrara um pião, que o agride violentamente, e depois the rasga a roupa, para regozijo dos demais, enquanto Luzinete, que acompanha o grupo, a quem Amâncio Amaro protegera, amara e ajudara, assiste a tudo com indiferença, refugiando-se no mato, para entregar-se a cada um dos meninos.

Além de aprofundar o debate acerca do relacionamento humano, A paixão de Amâncio Amaro ratifica a crise e a obsolescência que reciclam a oferta de bens em nome de uma modernidade tardia, quase sempre tornada 
inócua. Nas diferentes áreas do Nordeste, fitas e relíquias religiosas, bonecos e utensílios de cerâmica, garrafas de areia colorida, redes e esculturas, estatuetas de Lampião e do Padre Cícero e folhetos de cordel são destituídos do sentido intrínseco, relacionado ao lazer, à cultura e à religiosidade, para se converterem no fetiche consumista do turismo predatório, que se impõe à condição de dependência econômica da região. Locais específicos como o Mercado Modelo, em Salvador, o Mercado São José, em Recife, e o Mercado Central, em Fortaleza, as três maiores cidades da região, há muito perderam seu significado, no que tange à relação da oferta de bens à população local, deslocada para os supermercados e shopping centers, para que seja atendida a exclusividade dos pacotes turísticos que despejam nesses centros levas de consumidores ávidos pela aquisição de souvenirs, antes estritamente ligados à tradição e à cultura utilitária dos que na terra constroem sua vida e sua história.

\section{Referências}

APPADURAI, Arjun. La modernidad desbordada: dimensiones culturales de la globalización. Montevideo, Buenos Aires: Ediciones Trilce, Fondo de Cultura Económica da Argentina, 2001.

APPADURAI, Arjun O medo ao pequeno número: ensaio sobre a geografia da raiva. São Paulo: Iluminuras, Itaú Cultural, 2009.

BAUMAN, Zygmunt. O mal-estar na pós-modernidade. Rio de Janeiro: Jorge Zahar, 1998.

BHABHA, Homi. O bazar global e o clube dos cavalheiros ingleses. Rio de Janeiro: Rocco, 2011.

BHABHA, Homi. O local da cultura. Belo Horizonte: Editora UFMG, 2005.

BOSI, Alfredo. Cultura como tradição. In: BORNHEIN, Gerd et alii. Cultura brasileira: tradição/contradição. Rio de Janeiro: Jorge Zahar/Funarte, 1987.

BOURDIER, Pierre. A economia das trocas simbólicas. São Paulo: Perspectiva, 1998.

CANCLINI, Néstor García. As culturas populares no capitalismo. São Paulo: Brasiliense, 1983.
CANCLINI, Néstor García. Culturas híbridas: estratégias para entrar e sair da modernidade. São Paulo: Edusp, 2000.

CUNHA, Euclides da. Obra completa. Vol. 2. Rio de Janeiro: Nova Aguilar, 1995.

DIAS, Ângela Maria. Representações contemporâneas da crueldade: para pensar a cultura brasileira recente. In: DIAS, Ângela Maria; GLENADEL, Paula (Org.). Estéticas da crueldade. Rio de Janeiro: Atlântica Editora, 2004.

FERRARA, Lucrécia D’Alessio. O mapa da mina. Informação: espaço e lugar. In: SANTOS, Milton et al. (Org.). O novo mapa do mundo: fim de século e globalização. São Paulo: Hucitec, Ampur, 1994.

GIDDENS, Anthony. Modernidade e identidade. Rio de Janeiro: Jorge Zahar, 2002.

HALL, Stuart. A identidade cultural na pós-modernidade. Rio de Janeiro: DP\&A Editora, 2004.

HALL, Stuart. Da diáspora: identidades e mediações culturais. Belo Horizonte, Brasília: Editora UFMG, Representação da UNESCO no Brasil, 2003.

IANNI, Octavio. A era da globalização. Rio de Janeiro: Civilização Brasileira, 1997.

LAURENTINO, André. A paixão de Amâncio Amaro. Rio de Janeiro: Agir, 2005.

LYOTARD, Jean-François. A condição pós-moderna. Lisboa: Gradiva, 1989.

MARTIN-BARBERO, Jesús. Dos meios às mediações: comunicação, cultura e hegemonia. Rio de Janeiro: Editora UFRJ, 2001.

MIGNOLO, Walter D. Historias locales/diseños globales: colonialidad, conocimientos subalternos y pensamiento fronterizo. Madrid: Ediciones Akal, 2003.

ORTIZ, Renato. Mundialização e cultura. São Paulo: Brasiliense, 1998.

SEMPRINI, Andrea. Multiculturalismo. Bauru: EDUSC, 1999.

SUBIRATS, Eduardo. Da vanguarda ao pós-moderno. São Paulo: Nobel, 1991.

Recebido: 02 de abril de 2016.

Aprovado: 02 de julho de 2016.

Contato: valdemarvalente@gmail.com 